\title{
Nominal negative quantifiers as adjuncts
}

\author{
Josef Bayer
}

Abstract The topic of the following article is an exceptional use of the negative quantifier nothing and its correspondents in German, Dutch and Italian in which this element turns out to act like a negative polarity item (NPI). The circumstances under which this is the case have very briefly been described in Bayer (2006). Nothing is interpreted like an NPI whenever it is not licensed as an argument. Closer inspection reveals that adjunct status alone is too coarse a distinction, and that nothing must in fact be associated with the structural object position of the verb. The article is organized as follows. Section 1 presents the key observation using English data. Sections 2, 3 and 4 present constructed as well as attested data from English, German and Dutch respectively. Section 5 contains considerations of argument structures which trigger the interpretation of nothing as an NPI. Section 6 presents the core account. Section 7 sketches a diachronic scenario. Section 8 turns to negative concord and expands the account to Italian data. Section 9 contains a conclusion.

Keywords Argument structure $\cdot$ Diachrony $\cdot$ Negation $\cdot$ Negative polarity Negative strengthening

\section{The key observation}

In modern English, nominal negative quantifiers such as nobody and nothing according to traditional wisdom serve two functions: they fill an A-position, and they negate the containing proposition. ${ }^{1}$
(1) a. Nobody was interested.
SUBJECT
b. I could trust nobody.
OBJECT
c. Nothing went wrong.
SUBJECT
d. I ate nothing.
OBJECT

\footnotetext{
'Throughout this article I will use the terminology 'negative quantifier' or 'NQP' in a purely descriptive way in order to refer to n-words like nothing. Semantically these phrases are presumably neither genuine quantifiers nor are they the actual exponents of sentential negation.

J. Bayer $(\bowtie)$

Department of Linguistics, University of Konstanz, 78457 Konstanz, Germany

e-mail: josef.bayer@uni-konstanz.de
} 
A plausible and widely accepted assumption about the structure is that the negative quantifier (NQP) activates a Negation Phrase (NegP) whose head remains silent. Let us follow Pollock (1989), Haegeman and Zanuttini (1991), Acquaviva (1993), Haegeman (1995) and others who have proposed a NegP in which a neg-head (which is either empty or filled with a morpheme of negation) may associate with an NQP in one way or the other, a process which leads to cancellation of the neg-feature of the NQP. Of the different technical implementations (which are not in the center of the present article) a feasible one may follow from a combination of minimalist syntax with the semantic account of indefinites of Heim (1982). Under such an account the neg-head values the (uninterpretable) neg-feature of the NQP leaving behind an indefinite. If we follow Heim (1982) and take the indefinite as a restricted variable which is existentially bound via a default operation, we arrive at a tripartite semantic representation of the examples in (1) as in (2) in which the NQP appears to be properly decomposed into a neg-feature which is ultimately checked by sentential negation, a restricted variable and an existential quantifier which binds it. ${ }^{2}$

(2) a. $\neg(\exists x, x \in$ PERSON, $x$ was interested $)$

b. $\neg(\exists x, x \in$ PERSON, I could trust $x)$

c. $\neg(\exists x, x \in T H I N G / E V E N T, x$ went wrong $)$

d. $\neg(\exists x, x \in$ THING, I ate $x)$

Once the 'logical' features have been stripped off, the residue of the NQP can be identified with the restricted variable that satisfies the argument structure of the contentive verbal head of the clause.

Notice now that there are cases which in one sense escape this schema because the nominal element nothing is licensed without filling an A-position. The following examples in which nothing follows an intransitive verb were found on the internet.

(3) I know the Mayor and he looks nothing like that.

(4) okay, my dentist's chair looks nothing like that

(5) First of all she talks nothing like that, second of all, ...

(6) Okay, so he looks and talks nothing like that character, but he has the same hat and $\mathrm{cab}$.

(7) Now I've burned discs that my player had a difficult time reading before and this current situation appears nothing like that.

(8) The StoreFront web site says that their software is highly flexible and scalable, and tops in the industry. It appears nothing like that to us. Am I missing something?

(9) My car runs nothing like that though.

(10) Actually, I don't know why they call it goose step. Geese walk nothing like that.

(11) It is simply the arc plane physics. A dodo flies nothing like that.

In all these cases, nothing (like that) represents sentential negation but at the same time has the flavor of emphasis or strengthened negation which is typically found in

\footnotetext{
${ }^{2}$ For an overview of various syntactic and semantic accounts of negation, see Weiß (2002b). His approach is close to my own assumptions, some of which were initially formulated in Bayer (1997), cf.
} 
negative sentences with a Negative Polarity Item (NPI). For instance, (3) can be successfully paraphrased as in (12).

(12) I know the Mayor and he doesn't look anything like that at all.

Significantly, this NPI-interpretation is missing in cases like (1) in which the NQP is associated with an argument position. (1d), for example, does not mean the same as $(13) .^{3}$

(13) I didn't eat anything at all.

The first question to ask is whether nothing like that is a standing expression in which nothing contributes negation and the comparative anaphoric part like that is the NPI proper. In the following section we will take a closer look at English data, and we will see that this does not lead to a satisfactory account.

\section{English}

Although examples with nothing like that appear to be very frequent, there is variation as one can see in the following two quotes from William Shakespeare and from Mark Twain. ${ }^{4}$

(14) My mistress' eyes are nothing like the sun

(William Shakespeare, Sonnet 130)

(15) I pray thee of thy grace believe me, I did but speak the truth, most dread lord; for I am the meanest among thy subjects, being a pauper born, and 'tis by a sore mischance and accident I am here, albeit I was therein nothing blameful. I am but young to die, and thou canst save me with one little word. Oh speak it, sir!

(Mark Twain, The Prince and the Pauper Chapter 5)

The next examples show nothing in combination with the deverbal adjective daunted which means something like 'discouraged'.

\footnotetext{
${ }^{3}$ This should not mean that (1d) cannot be strengthened toward an NPI-interpretation. Extra stress on nothing would have such an effect. For mechanisms of widening and strengthening utterances with any cf. Kadmon and Landman (1993). While any has a general domain widening effect (p.368), it does not as such turn its complement into an NPI. If it did, strengthening with at all as in (13) would not be expected. Paolo Acquaviva (p.c.) points out an example of strengthening from Old Italian which in addition shows a non-argumental use of niente (which in Italian also occurs in Niente lavoro, niente soldi! 'no work, no pay!').

(i) Sono alquanti suoi doni (cioè dello Santo Spirito) senza i quali in nessunomodo niente are some his gifts i.e. of-the holy spirit without the which in no way nothing si può andare a vita eterna

REF can go to life eternal
}

'There are some of the Holy Spirit's gifts without which one cannot under any circumstances at all reach eternal life.' from: Tommaseo and Bellini (1859-79) (http://www.dizionario.org/) More on Italian niente will follow in section 8 below.

${ }^{4}$ Thanks to Larry Horn (p.c.) for drawing my attention to the data in (14) through (18). 
(16) After this the enchanted axe cut off my arms, one after the other; but, nothing daunted, I had them replaced with tin ones.

(Frank L. Baum, The Wonderful Wizard of $\mathrm{Oz}$ )

(17) Nothing daunted, Anne proceeded onward to the church alone.

(Lucy Maud Montgomery, Anne Of Green Gables)

(18) But, nothing daunted, he jumped to his feet and cried ...

\section{(Carlo Collodi, The Adventures Of Pinocchio)}

In these quotations, nothing daunted means 'not discouraged at all'. According to the OED, there is an adverbial usage of nothing which is glossed as 'not at all', 'in no way', and is considered to be "now archaic". Nevertheless, the following internet finds with intransitive verbs are from speakers of contemporary English.

(19) sleep

a. Inside, Lizzette's mother, Rubi Soria, slept in a bedroom, exhausted from crying. 'She has slept nothing all night,' Alejandro Peña said.

b. Last 2 weeks I was everyday too late in my bed! All Vince's fault, and now I'm everly tired. See Monday and Tuesday I slept nothing, all because of him.

c. I have slept nothing for I've been thinking of you.

(20) dance

cheers. actually I danced nothing. not that I didn't dance, but I did it in the manner of nothing. not in a good way though.

(21) complain / protest / lobby

a. I am staying here now..... AS and RA this place sucks! room upgrade to a business room nothing special.... I complained nothing, I even called London to complain to the RA service ...

b. Funny you would label me a protester when in fact I have protested nothing and am not advocating a withdrawal.

c. Bobby is a simple man. He has done nothing of great notoriety. He has penned no unforgettable lyrics, composed no music, erected no architecture, written no profound works, accumulated no wealth. $\mathrm{He}$ has protested nothing and lobbied nothing.

d. Christians have not stood up for evil. They have sat back and protested nothing.

The following examples of the use of work show that an NPI can still be added.

(22) work

a. the main USB hub worked nothing at all, though strangely other USB parts did. ${ }^{5}$

\footnotetext{
${ }^{5}$ Examples with VP-ellipsis like (22a) are highly informative as they show that both the neg-feature and the lexical part which gives rise to the NPI-interpretation must have disappeared from the semantic representation that substitutes the elided part at LF. Cf. Merchant (2000) for data and an account of antecedent-contained deletion in examples such as (i),

(i) That boy won't [do a damn thing I ask him to [vp] as well as Weiß (2002b: 137).
} 
b. If I work nothing at all - for one week - I will receive $\$ 76$ from unemployment.

c. Surface area is what makes intercoolers work, that tube is going to work nothing at all like an intercooler.

Uses of nothing which trigger an NPI-effect can also be found with predicative adjectives like afraid, pleased, short of, etc. ${ }^{6}$

(23) afraid / pleased / short of

a. Liga $(=\mathrm{a} \operatorname{dog})$ is very delicate, adores children, is ready to play with them during all days. She is nothing afraid.

b. I am nothing pleased with inculcation or wresting-in of matters, ...

c. Most of their answers, and a number of the negotiations we have had with them, witness that they were nothing short of us, ...

On the basis of such findings one can conclude that the 'adverbial' usage of nothing that the OED mentions is still part of the productive part of the current system of negation in English, perhaps with a restriction to certain sociolinguistic registers. Importantly, this non-argumental use of a nominal appears to be confined to nothing. To my knowledge, there are no non-argumental occurrences of nobody. Given this, we arrive at the following generalizations.

(24) Generalizations about English nothing

(i) Nothing triggers an NPI-reading only in its adverbial usage. ${ }^{7}$

\footnotetext{
${ }^{6}$ Further strengthening with at all would, of course, also be possible in these cases.

(i) God die makere es alre dinc/dat nie was of lijf ontfinc god who maker is (of) every thing that (n)ever was or life received 'God who is the creator of all things that ever were or sprung to life'

(ii) dat hi die beste ridder was / die noit quam in sconinx hof that he the best knight was that (n)ever came in the-king's court 'that he was the best knight that ever came to the king's court'
}

${ }^{7}$ One reviewer doubts that nothing is an NPI. The fact that we can add another NPI seems to nourish this doubt. On the other hand, adjunct nothing gives rise to strengthening even without such additions and without adding extra stress etc. Given that the class of so-called NPIs is far from homogeneous, the doubts may concern terminology more than the subject matter. Notice also that $n$-words have been identified in older stages of Germanic which can only be understood as NPIs. Hoeksema (1997) provides the following examples from Middle Dutch in which nie and noit cannot be sentential negators but make perfect NPIs.

Hoeksema argues that in the Middle Dutch period n-words must at least have been ambiguous between NQPs and existential QPs in the sense of NPIs. The following Old English example from Beowulf, taken from Beukema and Tomic (1995), shows that the lexical element wiht, which is historically part of English not as well as of German nicht, appears in its bare form in a negated clause where it can hardly be anything else but an NPI.

(iii) wihte ne wene
in-any-way not think-1SG
'I don't think at all'

Similar usages of wiht exist in OHG as Helmut Weiß (p.c.) points out to me. Apart from this, there is a substantial part of theoretical research on negation which attributes NPI-status even to argumental NQPS which depend on a c-commanding neg-head. Thus there is no reason for an a priori exclusion of NQPS from the class of NPIs. We will return to the relation between NQP and NPI in section 7 below. 
(ii) In its adverbial usage nothing encodes both (the feature of) sentential negation and an NPI.

In the next two sections, we will take a look at German and Dutch in order to explore whether the finding about non-argumental nothing is more than just an idiosyncrasy of English.

\section{German}

German nicht used to correspond to English nothing in containing an $n$-morpheme of negation and a nominal part for 'thing' - wiht - which unlike English thing can only be traced historically. ${ }^{8}$ The contemporary indefinite pronominal nichts derives from the Middle High German (MHG) genitive form nihtes. The analysis as a genitive became obsolete in the 14th century, as a consequence of which nichts began to be used like a nominative or accusative NP. Paul (1919/1954: vol.III, 224) observes that the negator nicht has turned from its original nominal category in MHG into an adverb only after nichts has been established as a nominal. ${ }^{9}$ Until the 19th century, nicht and nichts appear to some extent exchangeable as long as nichts would not replace a structural (accusative) object position. The adverbial use of nichts is reported in the Grimm dictionary where its status as an emphatic negation comparable to durchaus nicht, gar nicht 'not at all' is explicitly mentioned. The following examples are from Early New High German (ENHG) and were taken from Grimm and Grimm (1852/1971).

(25) was got wol gefelt, das gefelt den selbigen spöttern nichts what god well pleases that pleases these very mockers nothing 'What pleases god this does not please these mockers at all' (Keisersberg)

(26) der glaube aber zweifelt nichts dran the faith however doubts nothing there-at 'however, faith does not cast any doubt on it' (Aventin)

(27) als gehorten sie nichts zur kirchen as belonged they nothing to-the church 'as if they didn't belong to the church' (Aventin)

(28) dasz er also sehr verblendet wäre, dasz er der fünf bücher Mosi nichts achtete that he so very misled would-be that he the five books Mose nothing respected 'that he would be so misled that he would not respect the five books of Mose' (Aventin)

(29) dasz er doch hierab nichts erschracke that he PRT here-from nothing frightened-became 'that he did not really get frightened from this' (Ringwald)

\footnotetext{
${ }^{8}$ The root appears in modern German in lexemes like Wicht (pejorative for 'guy') and Wichtel 'gnome' and has cognates in various Old Germanic languages. See also the previous note.

${ }^{9}$ The nominal origin of nicht can still be seen in the predicate zunichte machen 'to destroy' where nicht carries the parochial dative Case-marker -e. Cf. Jäger (2008) for a detailed description of the interlocked and overlapping changes that nicht and nichts underwent in the history of German.
} 
(30) ich frage nichts nach hohem pracht

$I$ ask nothing for high splendor

'I am not looking for high splendor' (Neumark)

This usage continues for a long time in history. (31) is from Goethe, (32) from Achim v. Arnim.

(31) mache was du willst, ich kann nichts denken; aber folgen will ich do what you want $I$ can nothing think but follow will I

'Do what you want, I cannot think; but I will be obedient' (Goethe)

(32) daß ihr Bruder sich gar nichts um sie bekümmere

that her brother REFL entirely nothing for her care

'that her brother would absolutely not care for her' (v. Arnim)

Similar examples can be found in Paul (1919/1954: vol.III, 224). In all of them, nichts can be replaced by nicht, however the contexts suggest throughout an emphatic character in the sense of an NPI reading.

Modern Standard German retains adverbial nichts with certain predicates in the presence of which it can alternate with the standard negation nicht.

a. Karl hat nichts gearbeitet.

Karl has nothing worked

b. Karl hat nicht gearbeitet.

Karl has not worked

The semantic difference is clear enough: While the unmarked negation in (33b) is well compatible with a situation in which Karl is an industrious man who happens to have stopped work for a certain period of time, (33a) implies that Karl was or is a sluggard. He did not work at all. A similar albeit somewhat weaker contrast can be observed in Das hat ihn acc \{nichts / nicht\} gekümmert 'This did not bother him' and in Das hat ihm dat $\{$ nichts / nicht $\}$ geschadet 'This did not harm him'.

In German dialects as well as in colloquial language and informal registers adverbial nichts can be found with high regularity. (34) is a constructed example of Bavarian which sounds perfectly natural to native speakers of the dialect.

(34) Biaschal, do wead fei nix radl g'foan!

boy here becomes PRT nothing cycle ridden

'Hey guy, you cannot ride your bike here!'

(35), with the intransitive verb greinen 'to cry', is from a Franconian dialect of Northern Bavaria, reported in Feller (1914: 14).

(35) Brauchst nix ze greina.

need-2SG nothing to cry

'You don't need to cry.'

Given the deontic usages of the verbs werden and brauchen which hold in these examples, the emphatic interpretation of nichts is quite naturally suggested in both of these cases. 
In the following, examples of non-argumental nichts are presented as they can be found on the internet. ${ }^{10}$ They are slightly substandard but clearly grammatical. Native speakers of German, including linguists, sometimes reject such examples spontaneously. In my view this is an experimental artifact of the metalinguistic task of judging grammaticality. There is a general tendency for speakers to be far more normative in metalinguistic tasks than in their spontaneous language production and comprehension. This is the main reason for relying almost exclusively on attested data in the present study. The examples below are fully within the range of colloquial spoken German.

(36) lügen 'to lie'

$\mathrm{Da}$ wird nichts gelogen.

there becomes nothing lied

'There will/must be no lying.'

(37) weinen / jammern 'to cry', 'to lament"11

Mausi war voll tapfer... nichts geweint, nichts gejammert

Mausi was fully brave nothing crying nothing lamenting

'Mausi was really brave ... no crying, no whining'

(38) herumspielen 'play around'

Ich habe aber außer dem SuperDrive an der Hardware nichts herumgespielt. I have however except the S.D. at the hardware nothing around-played 'But with the exception of the super drive I have not played around with the hardware.'

(39) schlafen 'to sleep'

Von Freitag auf Samstag hab ich aber fast nichts geschlafen. from Friday to Saturday have I however almost nothing slept 'However, between Friday and Saturday I hardly slept.'

(40) lachen 'to laugh'

a. Ich habe nichts gegessen nichts gelacht nur in meinem zimmer gehockt I have nothing eaten nothing laughed only inmy room sat und geheult.

and cried

'I stopped eating and laughing. I only sat in my room and cried.'

b. In den letzten tagen hab ich fast nichts gelacht, und jeder der mich in the last days have I almost nothing laughed and everyone who me kennt weiss dass ich sonst immer fröhlich bin und lache.

knows knows that I usually always happy am and laugh 'In the last few days I almost didn't laugh at all, and everybody who knows me knows that I am usually happy and laugh a lot.'

\footnotetext{
${ }^{10}$ As a methodological caveat, one has to be aware that examples from the internet may be contaminated. The authors may not be fully competent in the language they are using, they may be engaged in making linguistic jokes, they may use a fabricated insider language, etc. Nevertheless, if certain patterns recur frequently, one should be confident that such artifacts do not play a role, and that the data are truly representative of the native speaker's linguistic competence. To the best of my knowledge, artifacts can be excluded from the data that are being reported in the present study.

${ }^{11} \mathrm{Cf}$. Jäger (2008: 103f.) for an $\mathrm{OHG}$ example involving weinen.
} 
(41) schwindeln 'to cheat'

Ich habe nichts geschwindelt, ich habe nichts getan. Ich musste bloß

$I$ have nothing cheated I have nothing done I must only

immer bezahlen.

always pay

'I didn't cheat, I did nothing. I only had to pay all the time.'

(42) herumfummeln 'to fumble around'

Nein an der XLL hab' ich nichts herumgefummelt.

no at the XLL have I nothing around-fumbled

'No, I didn't fumble around with the XLL.'

Relevant examples with predicative adjectives, comparable to those in (23), are not frequent, but they do occur. Die Welt ist nichts nett 'The world is not nice at all', Aber ich war nichts zufrieden 'But I wasn't satisfied at all', Andere Wiedererweckte sind nichts freundlich 'Other reawaked ones are not friendly at all' are examples from reliable sources found on the internet.

Given the data from ENHG which have been reported above and the continuation of the use of nichts as an adjunct in non-normative varieties of German, there can be no doubt that the generalization about English nothing in (24) can be extended to German. Just like nothing, the nominal NQP nichts shows up in non-argument positions where it systematically yields a negative polarity effect.

\section{Dutch}

As can be expected, a similar situation may be found in Dutch. Hoeksema (1994) provides the following data.

(43) Dat kan me \{niet / niets / niet veel / weinig / geen bal\} schelen that can me not / nothing / not much / little / no ball differ 'It makes no/no big etc. difference to me'

The version with niet represents simplex negation. Those with niet veel and weinig are negative sentences due to a negative measure phrase. As Hoeksema observes, the version with niets appears to be on a par with the genuine NPI (geen) bal (actually 'testicle'). The following examples, provided by Jack Hoeksema (p.c.) confirm that the use of niets in non-argument position gives rise to an NPI-interpretation. The examples are said to be slightly substandard but grammatical.

(44) Je bent niets beter dan je vader. you are nothing better than your father 'You aren't any better than your father.'

(45) Je bent niks aardig. you are nothing nice 'You are not nice at all.' 
(46) Je bent niks niet lief. you are nothing not nice

'You are not nice at all.'

(46) is of special interest as it shows negative concord (NC). Niks - a colloquial version of niets - appears together with (and is arguably in the scope of) niet. Given that Dutch is head-final, niet must be the carrier of sentential negation here while niks is the dependent (and to-be-checked) element. It is likely to be in the specifier of niet. $^{12}$

Let me provide naturalistic data, again drawn from the internet, in order to show that the phenomenon cannot be considered a rare issue in Dutch, at least not if one is willing to pay attention to informal and colloquial registers.

(47) slapen 'to sleep'

a. vandaag is het ondertussen weer bijna 4 uur en heb weer nog niets geslapen today is it meanwhile again almost $4 o^{\prime}$ 'clock and have again yet nothing slept 'today it is meanwhile 4 o'clock, and I have again not slept yet at all'

b. Ik heb bijna niets geslapen, ...

I have almost nothing slept

'I have almost not slept at all, ...'

c. Ik heb dus bijna niets geslapen, steeds maar herhaald in mijn hoofd wat er I have thus almost nothing slept always but repeated in my head what there gezegd was

said was

'Thus I did almost not sleep at all, but always repeated in my mind what had been said'

(48) fietsen 'to cycle'

a. We hebben nog niets gefietst want we hadden een beetje rust nodig, we have yet nothing cycled because we had a little rest necessary vooral de knieën foremost the knees

'We hadn't cycled yet as we had to take a little rest, most of all the knees'

b. Niks gefietst vandaag, veel te lui voor nothing cycled today much too lazy for

'Not cycled today, much too lazy for it'

(49) huilen 'to cry' / protesteren 'to protest'

a. want hij is de hele tijd braaf geweest en heeft niets gehuild because he is the whole time well-behaved been and has nothing cried of geprotesteerd

or protested

'since he was always well-behaved and neither cried nor protested'

b. Ik heb een spuitje gehad en ik heb niets gehuild! Flink he! I have an injection had and I have nothing cried tough isn't it 'I got an injection, and I didn't cry at all. Tough, isn't it?'

\footnotetext{
${ }^{12}$ We will return to $\mathrm{NC}$ in section 8 .
} 
c. Ik ben gedurende de vlucht een superbrave meid geweest en heb niets gehuild I have during the flight a super-brave girl been and have nothing cried 'During the flight I was a super brave girl and didn't cry at all'

The occurrence of the NQP in non-argument position which triggers the NPIeffect is obviously not unconstrained. In the next section we will take a look at the lexico-syntactic environment in which NQPs with this function occur and try to find a generalization about the argument structures involved.

\section{Argument structure ${ }^{13}$}

The majority of uses of adjunct nothing which trigger an NPI-interpretation are confined to intransitive verbs or verbs with a selected PP. For English, a cursory search for transitive verbs yielded results for the verbs help and bother, the example in $(50 \mathrm{f})$ being from an 18 th century text.

(50) a. But all his sorrowing helped him nothing

b. but it helped him nothing at all

c. The small glass of cognac before him helped him nothing

d. Her conversion and sincereity helped her nothing, she was executed when Britain failed to accede to demands that British Forces be withdrawn.

e. Mrs. Yaverland turned on Ellen a glance which recognised her quality as queer and precious, yet was not endearing and helped her nothing in the girl's heart.

f. Last year I saw with my own eyes that an Indian killed his own wife in broad daylight in the street here in Philadelphia, and that bothered him nothing.

(Gustavus Hesselius, 1714)

Typically, help is only used non-agentively, bother as a psych-verb. Among the German examples above, gefallen in (25) is a psych-verb with DAT <NOM; achten in (28) is agentive but with a NOM $<$ GEN Case frame. Examples can also be found with psych-verbs like stören and kümmern. ${ }^{14}$

(51) obwohl mich das nichts stört

although me this nothing disturbs

'although I am not at all disturbed by that'

(52) In meiner Branche gibt es allerdings etliche Händler, die das nichts kümmert. in my branch are there however certain dealer who that nothing bothers 'In my field there are, however, certain dealers who are not worried by this in the least.'

For the verb helfen, only occurrences with a non-agentive subject were found, in agreement with the English data in (50).

\footnotetext{
${ }^{13}$ Special thanks to Cecilia Poletto (p.c.) for discussing relevant aspects of argument structure with me.

${ }^{14}$ One reviewer feels that in (51) nichts could be an argument. I am not aware of any use in which stören could be a 3-place verb though.
} 
(53) a. aber das hat mir nichts geholfen

but that has me nothing helped

'but this didn't help me'

b. Ich kenne mich dort nicht aus, hatte sogar einen Stadtplan dabei. -

I know REFL there not out had even a city-map along

Aber der hat mir nichts geholfen.

but this has me nothing helped

'I don't know the area there, I even had a city map with me, but it was not of much help.'

c. ... ist die Wahrheit, aber sie hilft mir nichts!

is the truth but it helps me nothing

'is the truth, but it (=the truth) is of no help for me'

The Dutch example in (43) shows the psych-verb schelen which has an ACC/ $\mathrm{DAT}<\mathrm{NOM}$ Case frame. Verbs in the passive voice are usually impersonal passives as in (34), (36), and (in all likelihood) in the following example from the internet.

(54) Altes auf neues Radlager ergibt schön gleichmäßige Ansatzfläche, es wird

old on new wheel bearing yields nicely even contact-area it becomes nichts geschlagen, ...

nothing hammered

'Old on new wheel bearing results in a highly even contact area. No hammering is necessary...'

German has a small class of NPIs which arise without a visible trigger. The accusative minimizer einen Dreck ('a dirt', in the sense of 'a damn') is such an item. It seems that non-argumental nichts and einen Dreck are often interchangeable. In the following, the (a) examples were found on the internet. The (b) versions are constructed but sufficiently plausible alternatives.

(55) a. dann wird es sie einen Dreck interessieren, ob ihr weiterspielt oder nicht then will it them a dirt interest whether you on-play or not 'then it will interest them a damn whether you guys keep playing or not'

b. dann wird es sie nichts interessieren, ob ihr weiterspielt oder nicht

(56) a. und es dann so aussieht, als ob es ihn einen Dreck kümmern würde, was and it then so appears as if it him a dirt bother would what aus ihr wird

of her becomes

'and it appears as if he gave a damn about what will become of her'

b. und es dann so aussieht, als ob es ihn nichts kümmern würde, was aus ihr wird

Nevertheless, examples with the NPI einen Dreck can also be found with transitive agentive verbs in which nichts would be inappropriate.

a. Das Sozialamt hilft uns einen Dreck da sie noch verheiratet sind the social security office helps us a dirt because theystill married are 'The social security office does not help us at all because they (= the speaker's parents) are still married.' 
b. (*)Das Sozialamt hilft uns nichts da sie noch verheiratet sind

While the subject in (57a) is understood as an agent, the subject in (57b) can only be understood as an instrument or stimulus. With an agentive interpretation, the example is ungrammatical. Example (58a) is from the internet. If we replace the NPI einen Dreck by nichts as in (58b), the result is ungrammatical.

(58) a. Der wird einen Dreck jemanden umbringen, der wird genau niemanden umbringen. he will a dirt someone kill he will exactly nobody kill 'He will not kill someone at all, he will kill clearly nobody.'

b. *Der wird ihn nichts umbringen, he will him nothing kill

This suggests that non-argumental nichts is in competition with an object position that is induced by the agentive subject. Recall that emphatic nichts was found only in impersonal passives. Again it turns out to be ill-placed in unaccusative passives whereas the NPI einen Dreck is compatible with them.
a. Der Fritz wird einen Dreck eingesperrt.
the Fritz becomes a dirt imprisoned
'Fritz will under no circumstances be imprisoned.'
b. ${ }^{*}$ Der Fritz wird nichts eingesperrt

The same contrast can be observed in connection with unaccusative verbs with or without the reflexive sich.
a. Dieser Safe wird sich einen Dreck öffnen. this safe will REF a dirt open 'This safe will not open at all.'
b. *Dieser Safe wird sich nichts öffnen
a. Der Bodensee friert diesen Winter einen Dreck zu. the Lake-Constance freezes this winter a dirt close 'Lake Constance will not freeze this winter at all.'
b. *Der Bodensee friert diesen Winter nichts zu

Although compiling the amount of data that would have to be explored to reach a firm conclusion is beyond the scope of the present investigation, here is a first characterization of the environment in which non-argumental nothing/nichts appears to be licensed. ${ }^{15}$

(62) Generalization about the attachment of non-argumental NQP

The non-argumental NQP nothing/nichts is merged in the structural object position of a predicate to which no theta-role has been assigned. ${ }^{16}$

\footnotetext{
${ }^{15}$ In the absence of field work on Dutch, I must limit myself here to English and German.

${ }^{16}$ Non-isomorphy of theta position and Case position is most common as function-changing operations show. Staudinger (1997: 168ff), to whom an anonymous reviewer drew my attention, discusses resultative constructions in German such as Peter hat seine Partnerin müde getanzt 'Peter danced his partner tired' with the question how the object licensed by the result predicate, seine Partnerin, could ever receive accusative Case if not from the verb tanzen which, however, is intransitive. Straightforward examples are also cognate objects, which are Case-licensed without having argument status.
} 
It is unfortunately not entirely clear what counts as the structural object position. The uncontroversial case is the prototypical object of an agentive verb, cf. Dowty (1991). An accusative experiencer as in German Das Buch NOM $_{\text {interessiert ihn }}$ nicht 'the book does not interest him' is certainly different as seen by the inability to passivize $\left({ }^{*} E r\right.$ wird nicht von dem Buch interessiert) or to form the middle $\left(^{*} E r\right.$ interessiert sich leicht durch solche Bücher). German datives are distinct from structural objects. Why they appear to reject merger of the NQP in the context of an agentive subject (cf. (57b)) but not in the context of an instrumental subject is not entirely clear at the moment. The reason could be that in the latter case the argument structure is reversed according to the animacy hierarchy which introduces the (animate) experiencer as the external argument leaving the stimulus/instrumental argument in the VP. As this argument receives nominative Case, the structural object position is free. ${ }^{17}$ Intransitives with an agentive subject (unergatives) obviously have a non-argumental structural object position in which they can license NQPs while unaccusatives do not. Another class of verbs which appear with NQPs that give rise to an NPI-interpretation are meteorological verbs. The following English and German examples were found on the internet.

rain, snow

a. 'TYPICAL Windhoek. Either it rains nothing or it all comes pouring down at once,' said ex-Miss Namibia finalist Chantal van Taak yesterday morning ...

b. It has snowed nothing here

c. I live in England, it snowed nothing today! And we got 0 inches!

(64) regnen 'to rain', schneien 'to snow', blitzen 'to lighten', donnern 'to thunder'

a. Bei uns, am Rande der Cevennen in Südfrankreich, hat es in at us at-the border the C. in South-France has it in den vergangenen neun Monaten praktisch nichts geregnet the past nine months practically nothing rained

'In our area at the border of the Cevennes in Southern France during the past nine months it has practically not rained at all'

\footnotetext{
${ }^{17}$ An indication of what is going on may be that even in English (where 'datives' usually can undergo NP-movement), the object of help rejects NP-movement in cases with an instrumental subject: *John was helped by $\{$ Mary $/ *$ this medicine $\}$. Kratzer (1996) develops argument structure in a now widely accepted way by introducing the external argument via a Voice-head (or little $v$ ) which is projected above VP and licenses an agentive subject if $\mathrm{V}$ assigns (or potentially assigns) accusative Case. The examples in (i) and (ii) show that in German it might be the direct object position per se that is relevant rather than the position which accusative Case is assigned to.

(i) *Ich habe meiner Frau (beim Abwasch) nichts geholfen

$I_{\text {NOM }}$ have my wife DAT $_{\text {at- }}$ the dish-washing nothing helped

(ii) Der Schutzanzug hat mir (bei der Kernschmelze) nichts geholfen

the protective-suit $t_{N O M}$ has me $e_{D A T}$ at the meltdown nothing helped

Folli and Harley (2007) adjust phrase structure with $v$ to the distinction of human (volitional) versus nonhuman/inanimate (non-volitional) causers: John ate the sandwich vs. The sea ate the beach away. Placement of the adjunct NQP is in both cases equally impossible. What matters is obviously nothing but the structural object position for which the NQP competes.
} 
b. In der Rhön hat es in dieser Saison bislang fast nichts geschneit in the Rhoen has it in this season so.far almost nothing snowed 'In the Rhoen, it almost didn't snow at all in this season so far.'

c. Es blitzt und donnert nichts, weil es keine Gewitter gibt it lightens and thunders nothing because it no storms gives 'There is neither lightning nor thunder because there are no storms.'

While in these constructions the NQP must be seen as unlicensed by argument structure, in other contexts some such verbs may in fact appear with an object, a fact which suggests that these meteorological verbs in principle leave room for a direct object.

(65) a. the year it rained money

b. Damn, I just wish it snowed money

a. ... der einzige Tag in der Woche war, an dem es kein Manna regnete the only day in the week was on which it no manna rained 'was the only day in the week on which it did not rain manna'

b. dass es zu Weihnachten wieder ordentlich Geschenke schneit that it at Christmas again properly gifts snows 'that it will again properly snow down gifts at Christmas'

In the next section we will explore how the insertion of the NQP can yield sentential negation while simultaneously giving rise to the NPI-effect that has been observed in the data throughout.

\section{Accounting for the NPI-effect}

In order to understand the NPI-effect that emerges as soon as nothing etc. is merged as a non-argument, it is important to know (i) that in the cases considered so far, the NQP activates sentential negation, and (ii) that the NQP nothing itself includes the lexical structure that triggers the NPI-interpretation. In other words, nothing is special as it fulfils two jobs at once, the establishment of negation and NPI-licensing. This is possible if we follow one of the standard assumptions about the syntax of negation, namely that there is a Negation Phrase (NegP) whose head is either overtly a morpheme of negation or is covertly identified as such. Identification of the NegP by NQP seems to be natural because negation has to be signaled somehow. ${ }^{18}$ Thinking first about argumental NQP, the NQP may be merged into the direct object position and will be licensed as a negative element as soon as merger to VP creates a neg-head which can value the unvalued neg-feature inherent in the NQP, $<\mathrm{uNeg}>$. I

\footnotetext{
${ }^{18}$ Cf. Acquaviva (1993: 42) who referred in the wake of Pollock (1989) to the role of an operator in the specifier of NegP. Together with Ladusaw (1992), Acquaviva was one of the first to notice that NQPs must ultimately turn into indefinites in the scope of negation. The operator in SpecNegP was responsible for that. Since then, the technical implementations in terms of copy movement and agreement at a distance have changed, but the original insight remains unchallenged.
} 
assume for concreteness that in a language without $\mathrm{NC}$ such as the standard varieties of Dutch, English, and German a silent neg-head will be merged to VP which engages in a probe/goal agreement relation with the locally accessible NQP. (67) demonstrates how NQP can license sentence negation according to a minimalist view of feature valuation. ${ }^{19}$

$$
\mathrm{Neg}^{\mathrm{o}}\left[\mathrm{vP} \ldots \mathrm{NQP}_{<\mathrm{uNeg}>}\right] \quad \Rightarrow \quad \underbrace{\mathrm{Neg}^{\mathrm{o}}\left[\mathrm{vp} \ldots \mathrm{NQP}_{\langle\mathrm{tNeg}\rangle}\right]}_{\mathrm{AGREE}}
$$

A sentence like She ate nothing will turn into a structure in which the NQP has been stripped of its neg-feature while the semantically relevant negation now rests solely in the head of NegP, i.e., the sentence reads as 'It is not the case that she ate something, ${ }^{20}$ The abstract presence of sentential negation is shown by tag tests as in She ate nothing, and HE didn't either. The residue of nothing that remains after feature valuation is the existentially bound restricted variable as seen in (2) above. To be sure, the residue which is handed over to semantics proper is not a negative expression any longer. Neg could also have an EPP-feature in which case NQP would undergo overt movement to $\mathrm{SpecNegP}$ and engage in feature valuation under what is known as spec-head agreement. This is now standardly assumed for Bavarian NC-constructions where NQPs raise to SpecNegP.

To return to the core issue of this article, namely the nominal NQP as an adjunct, assume now that the NQP can freely be merged into a virtual DO-position even if there is no argument structure which would lexically demand such a position. Although we must leave the exact reason for this possibility open, the available data and the considerations in the previous section suggest that merger of the NQP has something to do with structural Case assignment. Since nothing, nichts, niets are NPs, they need to have Case. German provides evidence that nichts (together with a class of other bare indefinite nominals) lacks a morphological Case paradigm and

\footnotetext{
${ }^{19}$ It is important to notice here that I deviate from the Chomskyan standard theory by assuming an uninterpretable neg-feature in the goal and an interpretable neg-feature in the probe, exactly the opposite of what the standard theory proposes. A strong motivation to do so comes from NC. NC may affect an unlimited number of NQPs which in the process of feature valuation get rid of their neg-feature. In all the cases in which a positionally fixed neg-head (head of NegP) can be found, it is the NQP's neg-feature that disappears, and not the neg-feature of the head. This is exactly what Weiß (2002a) assumes for NC in Bavarian, and Penka and von Stechow (2001) for Standard German. For a theory of agreement in terms of feature sharing which remains neutral w.r.t. the locus of feature deletion cf. Pesetsky and Torrego (2007) and Brody's (1997) proposal of Radical Interpretability.

${ }^{20}$ There are, of course, technical alternatives. There could be LF-movement of nothing, there could be feature-movement of the relevant substructure of the NQP, and there could be overt movement of the NQP to SpecNegP followed by remnant movement which obscures the actual positioning of the NQP as in Kayne's (1998) account. I will follow the minimalist proposal without discussion of these issues as they are outside the scope of this article.
} 
can as such only be structurally Case-licensed. ${ }^{21}$ This distinguishes the NQP from overtly Case-marked DPs ("free" accusatives) such as den ganzen Tag "the whole day' or einen Dreck 'a dirt' which are licensed outside the system of structural Case and may thus be considered to have lexical Case. If the NQP is merged in a structural Case position without the license of argument structure, the same valuation process as in (67) will apply, though with one noticeable side effect: the semantic remnant of nothing, 'thing', will survive in core syntax as shown in (68b).
a. She ate nothing
$\Rightarrow$
She NOT ate whing
+OBJECT
b. She slept nothing $\Rightarrow \quad$ She NOT slept nething
-OBJECT

It does not require much fantasy to see that the seemingly superfluous element THING is the element that triggers the NPI-effect. In (68a) the standard interpretation can apply according to which THING is the minimal (and perhaps contextually enriched) restrictor of a variable $x$ that will by default be bound by an existential operator. An anonymous reviewer suspects that (68b) should be interpreted accordingly. But for this to be possible, THING has to be the restrictor of a variable. Given that the argument structure of sleep does not provide an internal argument, there can be no variable and no related existential stipulation. ${ }^{22}$ Viewing it from a different perspective, the status of THING as a semantic restrictor would be equally unclear. Things which are eaten are likely to be edibles. What would things be which are being slept?

It is certainly not an accident that the expression $a$ thing is one of the NPIs that occur in the English language. A viable alternative to (68b) would be (69).

(69) She didn't sleep a thing.

Examples from the internet with the NPI a thing are given in (70).

(70) a. I rode that trail on my hardtail and didn't walk a thing.

b. I didn't talk a thing about work.

${ }^{21}$ For example, nichts cannot be merged as an object of a verb that requires dative Case such as ähneln 'to resemble'. This can be seen in the contrast between (i) and (ii) where only the full DP is overtly Case marked.

(i) *Dieses Objekt ähnelt nichts

this object resembles nothing

(ii) Dieses Objekt ähnelt kein-em Würfel

this object resembles no -DAT cube

For relevant discussion of structural versus morphologically expressed Case in German cf. Bayer, Bader and Meng (2001) as well as Bayer and Bader (2007).

22 Of course, it is equally impossible to associate nothing in this case with a referential adjunct in the sense of Davidsonian event semantics. 
c. They don't talk a thing about general Musharaf at all, they just talk about political parties.

d. My level didn't help me a thing.

e. It don't interest me a thing to show my picture at 61 .

f. Durza cuts Eragon in the back, but somehow it doesn't bother him a thing.

In all these examples semantic composition would run into serious problems if THING would be taken to restrict a variable as introduced by the verb's argument structure. On the other hand, the morphological structure of the NQP that allows the parse neg+thing maps in a rather direct way into the syntactic structure according to which an NQP must be decomposed so as to fulfill the double duty of identifying a neg-head (and become a target for neg-feature valuation) and satisfy argument structure. The specialty of non-argumental NQP is that the orphanized element THING gives rise to the interpretation of 'strengthened' negation that is typical for negative sentences with NPIs.

My prediction is that the NQP as such triggers an NPI-effect only in contexts where THING does not fill an A-position as provided by argument structure, i.e. where THING is indeed orphanized. NQP in an A-position as provided by argument structure is not sufficient to invoke the NPI-effect because THING is a proper restrictor that identifies the required argument. An NPI-effect can in this case only be achieved by additional means such as extra stress or by the attachment of an independent NPI as seen in (71).

(71) a. She ate nothing at all.

b. She ate nothing whatsoever.

One may ask what my account predicts for cases in which the NPI a thing is merged into the direct object position. This NPI is in need of an overt signal of nonveridicality as in (72).

(72) a. At the dinner last night she didn't eat a thing.

b. Who would eat a thing in this restaurant?

c. In this restaurant, did she eat a thing?

d. I would be happy if she (only) ate a thing.

(72a) clearly has an NPI-interpretation, unlike At the dinner last night she ate nothing. We must conclude that the very form of $a$ thing as provided by the lexicon is distinct from the element that equals the restrictor part after the decomposition of nothing. Only the former is explicitly listed as an NPI. Given this, it is all the more remarkable that the NPI-interpretation is conditioned by the lack of an argument license of the bare NQP.

In the next section it will be shown that my explanation of the NPI-effect at hand fits rather naturally into the diachronic development of negation.

\section{Diachrony}

Modern English overtly shows that the lexical part thing inherent in the NQP nothing is also part of the NPI a thing. Although German nichts is lexically less 
transparent, the same organization as in English is at work, as shown by the diachronic development of negation in this language. ${ }^{23}$ As Jespersen (1917) and much following work could determine, the older carrier of sentential negation was a verbal prefix, in OHG $n i$, later also en. Negation could be 'strengthened' by - among other strategies - insertion of the complex element ni-wiht or also, with the generalizing particle -io, ni-o-wiht ('no-thing', 'no-whatever-thing'). ${ }^{24}$ This is attested in forms like ih enweiz niht ... (I neg-know neg-thing, 'I don't know ...'). According to Jespersen's Cycle, niwiht, which became opaque by changing into niht, became obligatory at some stage and the negative prefix gradually disappeared. ${ }^{25}$ Next to niwiht other neg-dependent elements were also in play, e.g., nihhein 'notone' which changed ultimately into the negative determiner kein 'no', another lexical element which establishes an NQP in modern German without being an NPI. However, as Donhauser (1996) points out, kein also survived the disappearance of the prefix ni/en as a 'positive' indefinite for a long time. ${ }^{26}(73 \mathrm{a})$ is from a MHG text, $(73 b)$ is $\mathrm{ENHG}$.

a. wär er mir keine wile bi, er lieze sine untugend be $e_{\mathrm{SUBJ}}$ he me $\mathrm{DAT}_{\mathrm{DAT}}$ no while near he let $t_{\mathrm{SUBJ}}$ his vice 'Would he be near me, he would give up his vice' (Tristan)

b. mein gotlich hertze ist mer zu dir geneigt denn zu keinem Menschen my divine heart is more to you directed than to no man 'My divine heart loves you more than anyone else'

Typically, the negative determiner is licensed in a non-veridical context like in a conditional clause (73a) or a comparative construction (73b). Examples can be found as late as in the language of Goethe where kein was long established as a negative determiner. (74) shows the licensing of kein in a privative context.

...und es besteht ein Verbot, keine Kühe und Kälber zu schlachten and it exists a prohibition no cows and calves to butcher '....and there is a prohibition of butchering any cows or calves'

(Goethe, Italienische Reise)

A parallel example with nichts from the same source by Goethe is shown in (75).

Nun ist es zwar bei großer Strafe verboten, nichts in die canäle now is it however at great punishment prohibited nothing in the canals zu schütten noch Kehricht hineinzuwerfen; einem schnell einfallenden to pour nor waste in-to-throw a quickly approaching

\footnotetext{
${ }^{23}$ For more recent overviews see among others Zinsmeister (2003) and Jäger $(2005 ; 2008)$.

${ }^{24}$ For various lexical details and precise periodization cf. Jäger (2008).

${ }^{25}$ As Haegeman (1995) and Haegeman and Zanuttini (1991) show, West-Flemish retains optional en in negative sentences until today, as in:

(i) da Valère niemand (en-) kent that Valè nobody (not) knows 'that Valère does not know anyone'

${ }^{26}$ Also cf. note 7 above for data from Middle Dutch.
} 
Regenguß aber ist's nicht untersagt, ... rain-shower $_{\mathrm{DAT}}$ however is-it not forbidden

'It is at the risk of severe punishment forbidden to pour anything into the canals or to throw in waste, although a quickly approaching rain shower cannot be prevented to ...'

(Goethe, Italienische Reise)

The emergence of nichts from the neg-licensed niwiht and the continuation of its development in later stages as seen in these examples suggests that this item started out as an NPI. Prefixal negation having disappeared, NQPs superficially appear to be the primary carriers of clausal negation. The fact that NQPs come in different shapes and can be variably placed in the clause like DPs, makes this rather implausible, though. NQPs seem to be rather dependent on an abstract functional head which may be 'identified' by the NQP but is nevertheless responsible for the valuation of the neg-feature that is inherent in the NQP. ${ }^{27}$ If this interpretation of the diachrony of negation is correct, the simultaneous existence of NQP as an identifier of sentential negation and as an NPI is expected.

Without trying to give a realistic periodization, the structural changes in the diachrony of negation in German can be structurally characterized by the following (possibly overlapping) stages.

Stage 1: The verb carries a negative morpheme which licenses a negative-marked nominal element such as nothing or niowiht (e.g., in direct object position). This nominal can be inflected for Case, allowing, in German, for the genitive Case niowihtes. ${ }^{28}$ The non-negative part of the NQP (perhaps among other lexemes) is used to strengthen negation in the sense of an NPI.

Stage 2: While still being used as an argument, niowiht is reanalyzed/grammaticalized as an adverb which, being the least marked element, takes over the role of the verbal neg-morpheme. Later the genitive form niowihtes is reanalyzed as an uninflected bare nominal. The preverbal neg-morpheme is eventually lost ("Jespersen's cycle").

Stage 3: NQPs either coexist with the adverbial negator ("negative concord' as presently seen in Bavarian) or identify sentential negation by being in construction with an empty neg-head. Although they normally do not evoke emphatic readings, their potential of serving as a strengthener of negation and as such as an NPI is kept alive (as I have shown so far).

\section{Negative concord}

The Dutch example in (46), Je bent niks niet lief (literally, 'you are nothing not nice') shows that in varieties which admit NC, non-argumental NQPs can arise together with

\footnotetext{
${ }^{27} \mathrm{Cf}$. Penka and von Stechow (2001).

${ }^{28}$ Genitive Case would be compatible with involvement of an elliptic DP and thus explain frequency that exceeds contexts of verbal assignment of genitive.
} 
an overt carrier of clausal negation, here niet 'not'. In languages in which NC is either optional or completely banned for prescriptive reasons one occasionally finds NPIs without an overt licenser. We have seen German examples involving the minimizer NPI einen Dreck 'a dirt' in (55)-(61). Similar ones appear in the following examples. ${ }^{29}$

(76) Das geht dich einen feuchten Kehricht an.

this goes you a humid refuse at

'This is none of your business.'

(77) Grimgerde interessiert sich einen Pfeifendeckel für deine Oper.

Grimgerde interests REFL a pipe-lid for your opera

'Grimgerde does not care for your opera at all.'

(78) ?Karlfried hat doch die Bohne Ahnung von Kategorialgrammatik.

Karlfried. has PRT the bean idea of categorial-grammar

'Karlfried doesn't have the slightest idea of categorial grammar.'

Unless we want to say that expressions of small quantities or despicable elements such as Dreck, feuchter Kehricht, Pfeifendeckel, and Bohnen are themselves carriers of negation - which is at this point not supported by anything - there must be an abstract licenser in the clause. If such a licenser is available, however, we support our conclusion that the NPI-interpretation of non-argumental NQP arises as a consequence of neg-feature valuation and the orphanization of THING. The important difference between NQP and minimizers such as those in (55)-(61) and (76)-(78) is that NQPs carry the feature $<$ neg $>$ and are thus able to engage in NC. Minimizer NPIs are different. ${ }^{30}$ We have already shown in section 5 that they are rather independent of argument structure. In fact, if they are inserted as a direct object of a transitive verb, the NPI reading fades away, giving rise to a literal and therefore often awkward interpretation, indicated with $\%$.

$$
\begin{aligned}
& \text { \%Gernot hat sich einen feuchten Kehricht gekauft. } \\
& \text { Gernot has REFL a humid refuse bought } \\
& \text { 'Gernot bought for himself humid refuse.' }
\end{aligned}
$$

\footnotetext{
${ }^{29}$ (78) is usually not accepted without an overt nicht but appears to me more or less acceptable even without overt negation. (76) and (77) show the standard case without overt negation, but the NPIs involved can also be found with 'fused' negation, namely with the determiner kein (neg+D, 'no'). A similar item in English is squat, cf. Horn (2001), which appears with verbs like sleep, work etc. and can be found with or without overt negation.

${ }^{30}$ This is also Jäger's (2005) conclusion. Penka and von Stechow (2001) argue strongly in favor of abstract negation. According to them, negative indefinites (NQPs) are NPIs, albeit special ones. In the absence of an NQP, sentential negation is expressed by nicht. Ignoring questions of movement to SpecNegP or neg-feature checking under probe/goal agreement, their proposal is not far from the standard idea of a NegP with spec-head agreement.

One reviewer speculates that the minimizers Dreck, feuchter Kehricht, and Pfeifendeckel may indeed have changed into the class of n-words, similarly to the French minimizer pas ('step'). That this is quite unlikely is shown by the impossibility of using them in the specifier of overt negation in the NC-language Bavarian.
}

(i) D' Anna hot-se \{an Dre:k / an Pfeifadeggl \} (*ned) fia-n Gustl interessiert. the Anna has-REF a dirt a pipelid not for-the Gustl interested

'Anna was not in the least interested in August.' 


$$
\begin{aligned}
& \text { \%Grimgerde schuldet Gernot einen Pfeifendeckel. } \\
& \text { Grimgerde owes Gernot }{ }_{\mathrm{DAT}} \text { a pipe-lid } \\
& \text { 'Grimgerde owes a pipe lid to Gernot.' }
\end{aligned}
$$

(79) has a prevalent reading according to which the object of Gernot's buying is indeed humid waste, and (80) suggests that what Grimgerde owes to Gernot is exactly the lid of a pipe.

One expectation from these findings is that in a language with obligatory $\mathrm{NC}$, nonargumental NQPs should show the regular appearance with an overt carrier of negation, in all likelihood the head of NegP, and give rise to an NPI interpretation. As pointed out by Cecilia Poletto (p.c.), this is true for various varieties of Italian. Old Italian niente cosi 'nothing such' has the same distribution as English nothing like that, and was only used with the distribution of an adverb, whereas niente as such can either be the regular NQP-object of a transitive verb or - if used in the direct object position of an intransitive verb - elicit the NPI-effect. The latter is seen in (81).

e non dormono niente

an not sleep-3pl nothing

'and they don't sleep at all'

(Bono Giamboni, 1240 - ca. 1292)

This kind of NPI-licensing with the NQP corresponding to nothing is retained in Veneziano, the dialect of Venice. ${ }^{31}$
a. Nol me piaze gnente. not-it me likes nothing
'I don't like it at all.'
b. Nol me piaze miga.
not-it me likes not
'I don't like it at all.'

Given that the clitics $-l$ and $m e$ close the open argument positions of piaze, notice that both gnente and miga must be non-argumental. However, gnente is nominal, and miga, being a minimizer, deriving from the word for 'crumb', might be too. The correspondence to the Germanic examples seems to be more than accidental. Interestingly, the correspondence goes even further than that. According to Poletto (2008; p.c.), gnente can only be used with psych-verbs or intransitives, while it is ungrammatical with transitive and unaccusative verbs. Compare (83) with (84).

\footnotetext{
${ }^{31}$ According to Cecilia Poletto (p.c.) many Northern Italian dialects have a sentential negative marker which corresponds etymologically to the NQP nothing. This is also true for Rhaeto-Romance where nia can be both the simplex negation as in (i) or an NQP-object.

(i) I mangi nia soni.

I eat not potatoes

'I do not eat potatoes.'

(ii) I mangi nia.

I eat nothing

'I do not eat anything.'

No NQP other than nothing shows an ambiguity between simplex negator, NQP-argument and NPIadjunct. The case seems to be comparable to the wh-element what which also appears in various functions. Cf. Jäger (2000) on German was and Westergaard (2009) on Norwegian.
} 
(83)

a Nol lavora gnente.

not-he works nothing

'He doesn't work at all.'

b Nol dorme gnente.

not-he sleeps nothing

'He doesn't sleep at all.'

(84)
a. *Nol leze gnente libri.
not-he reads nothing books
'He doesn't read books at all.'
b. *Nol magna gnente la roba dolse.
not-he eats nothing the stuff sweet
'He doesn't eat sweets at all.'
c. *Nol vien gnente.
not-he comes nothing
'He doesn't come at all.'

It appears that non-argumental gnente must be merged into the structural object position. The strong parallelism between Germanic and Romance suggests a nontrivial common feature in the syntax of negation that has to my knowledge not played a role in comparative syntax so far.

What the Italian varieties considered above show is that the NQP niente/gnente in its non-argumental usage behaves in full analogy to an argumental NQP. It appears in post-verbal position and is in construction with an overt neg-head. I take this as support for the view that in the Germanic varieties from English, German, and Dutch considered above there is likewise a locus of clausal negation which, however, remains silent as long as we are dealing with varieties in which $\mathrm{NC}$ is missing for one reason or the other. We have also seen that lexical NPIs (minimizers with descriptive content) behave differently. This suggests that nothing and its equivalents in other languages are special in displaying the NPI-effect only as a side effect of being orphanized by argument structure. If my interpretation is tenable, this indicates that the function of a particular lexical element as an NPI can survive 1000 years, and that it can do so even if the responsible lexical element - in English thing, in German wiht - has long been adopted into the functional vocabulary of the language.

Corblin, Depréz, de Swart and Tovena (2004) argue that n-words are quantifiers, and that all an n-word in English can do is act as a quantifier. This is in their view the reason for the absence of doubling. Considering French, they notice that personne can be seen as introducing negation on its own or as a variable related to a variable that is licensed from elsewhere. Their conclusion about $n$-words is, however, that they "have lost the ability to be licensed as negative polarity items by negation" (p. 437). What we see in English, German and Dutch as well as in Italian confirms this general impression but differs in one important aspect. The quote from Corblin et al. suggests that n-words have started their life as NPIs and have later given up this function thus turning themselves into carriers of negation. What we have seen here is that the original function of n-words as NPIs is still alive in the grammars of the languages under investigation, and that in spite of their lexical opacity this function is invoked in those cases in which the syntax does not integrate the restrictive part of the NQP - usually THING - as an argument. 


\section{Conclusion}

The analysis of nothing, nichts, niets, niente as a trigger of an NPI interpretation that has been presented in this article certainly contains some loose ends. What is certain, however, is that the observed effect is highly stable across constructions and languages. ${ }^{32}$ It arises with high reliability in contexts in which this most unmarked NQP appears in a potential (structural) object position while being unlicensed as a thematic object by argument structure. Nothing and its correspondents have in all likelihood started their life as NPIs but have given up this function in the course of the development of the syntax of negation in the relevant languages. NQPs have been fully integrated into the system of sentential negation. Genuine NPIs are distinct; in many cases they are minimizers. It could be shown that these NPIs are subject to more liberal licensing conditions. They appear to be on a par with adverbial accusatives such as German den ganzen Tag 'the whole day'. The hidden NPI-nature of nothing and partners comes to light as soon as their neg-feature has been valued by sentential negation $\left(\mathrm{Neg}^{\circ}\right)$ and the restrictor (THING) remains in core syntax up to semantic interpretation. We have argued that it is the orphanized restrictor that gives rise to the NPI reading.

It is my hope that the present or a superior account of this phenomenon will enhance our understanding of negative polarity and negation in natural language in general. $^{33}$

Acknowledgements For communications which underlie the research that has led to this article I wish to thank Paolo Acquaviva for arousing my interest in the topic of this article and for continued discussion, Ellen Brandner, Jack Hoeksema, Larry Horn, Richard Ingham, Richard Kayne, Uli Lutz, Cecilia Poletto, Henk van Riemsdijk, and two anonymous reviewers. Thanks also to the participants of the workshop on Microvariation in Quantificational Structures at the 29th Annual Meeting of the Deutsche Gesellschaft fur Sprachwissenschaft, Siegen, 28.02-02.03.2007. Responsibility for any mistakes is, of course, exclusively on my side. This work was supported by a grant of the Deutsche Forschungsgemeinschaft within the Konstanz SFB 471.

\footnotetext{
32 Emestina Carrilho (p.c.) informs me that the effect described here can also be found with nada 'nothing' in Portuguese.

33 As Richard Kayne (p.c.) points out, the phenomenon described here may in the end be part of a larger class of phenomena in which Case-bearing nominals appear in quasi-adjunct position. He points to examples like

(i) She looks something like her mother.

(ii) She looks something between 25 and 30 etc. (cf. Kayne 2005)

One difference between these and nothing is that they appear to be independent of the structural object status as (iii) shows and thus seem to be on a par with adverbial accusatives.
}

(iii) She loved her something like her mother.

Integrating these cases would clearly go far beyond the scope of the present article. 


\section{References}

Acquaviva, Paolo. 1993. The logical form of negation: A study of operator variable structures in syntax. Doctoral dissertation, Scuola Normale Superiore, Pisa. Published 1997 by Garland.

Bayer, Josef. 1997. Word order in Bavarian multiple negation. Handout. Wuppertaler Kolloquium.

Bayer, Josef. 2006. 'Nothing' / 'nichts' as negative polarity survivors? In Between 40 and 60 Puzzles for Krifka, eds. H.-M. Gärtner, S. Beck, R. Eckardt, R. Musan, and B. Stiebels. http://www.zas.gwzberlin.de/publications/40-60-puzzles-for-krifka/pdf/bayer.pdf.

Bayer, Josef, and Markus Bader. 2007. On the syntax of prepositional phrases. In Interface and interface conditions, ed. A. Späth, 157-179. Berlin: de Gruyter.

Bayer, Josef, Markus Bader, and Michael Meng. 2001. Morphological underspecification meets oblique case: Syntactic and processing effects in German. Lingua 111: 465-514.

Beukema, Frits, and Olga Tomic. 1995. Negation in English. A diachronic view. Folia Linguistica Historica 16: 123-135.

Brody, Michael. 1997. Perfect chains. In Elements of grammar, ed. L. Haegeman, 139-167. Dordrecht: Kluwer.

Corblin, Francis, Viviane Depréz, Henriette de Swart, and Lucia Tovena. 2004. Negative concord. In Handbook of French semantics, eds. F. Corblin, and H. de Swart. Stanford: CSLI.

Donhauser, Karin. 1996. Negationssyntax in der deutschen Sprachgeschichte: Grammatikalisierung oder Degrammatikalisierung? In Deutsch - typologisch, eds. E. Lang, and G. Zifonoun, 201-217. Berlin: de Gruyter.

Dowty, David. 1991. Thematic proto-Roles, argument selection, and lexical semantic defaults. Language 67(3): 547-619.

Feller, Otto. 1914. Das Fürwort in der Mundart von Gerolzhofen (Ufr.). Ein Beitrag zur Syntax der ostfränkischen Mundarten. Würzburg: Drescher und Reichart.

Folli, Raffaella, and Heidi Harley. 2007. Causation, obligation and argument structure: On the nature of little v. Linguistic Inquiry 38(2): 197-238.

Grimm, Jacob, and Wilhelm Grimm. 1852/1971. Deutsches Wörterbuch. Leipzig/Stuttgart: S. Hirzel Verlag. http://germazope.uni-trier.de/Projects/DWB.

Haegeman, Liliane. 1995. The syntax of negation. Cambridge: Cambridge University Press.

Haegeman, Liliane, and Raffaella Zanuttini. 1991. Negative heads and the neg criterion. The Linguistic Review 8: 233-251.

Heim, Irene. 1982. The semantics of definite and indefinite noun phrases. Amherst, MA: University of Massachusetts. Ph.D. dissertation.

Hoeksema, Jack. 1994. On the grammaticalization of negative polarity items. BLS (Berkeley Linguistic Society) 2: $273-282$.

Hoeksema, Jack. 1997. Negation and negative concord in Middle Dutch. In Negation and Polarity, eds. D. Forget, P. Hirschbühler, F. Martineau, and M.-L. Rivero, 139-156. Amsterdam: John Benjamins.

Horn, Laurence R. 2001. Flaubert triggers, squatative negation and other quirks of grammar. In Perspectives on negation and polarity items, eds. J. Hoeksema, H. Rullman, V. Sanchez-Valencia, and T. van der Wouden, 173-200. Amsterdam: John Benjamins.

Jäger, Agnes. 2000. Unterspezifikation am Beispiel des Pronomens 'was'. Zur Grammatik eines wElements. MA thesis, Friedrich-Schiller-Universität Jena.

Jäger, Agnes. 2005. Negation in Old High German. Zeitschrift für Sprachwissenschaft 24: 227-262.

Jäger, Agnes. 2008. History of German negation. Amsterdam: John Benjamins.

Jespersen, Otto. 1917. Negation in English and other languages. Copenhagen: A.F. Høst.

Kadmon, Nirit, and Fred Landman. 1993. Any. Linguistics and Philosophy 16: 353-422.

Kayne, Richard S. 1998. Covert vs, overt movement. Syntax 1(2): 128-191.

Kayne, Richard S. 2005. A short note on where vs. place. Ms. New York University.

Kratzer, Angelika. 1996. Severing the external argument from its verb. In Phrase stucture and the lexicon, eds. J. Rooryck, and L. Zaring, 109-137. Dordrecht: Kluwer.

Ladusaw, William A. 1992. Expressing negation. In Proceedings from SALT II, eds. C. Barker, and D. Dowty, 237-259. Ohio State University.

Merchant, Jason. 2000. Antecedent-contained deletion in negative polarity items. Syntax 3(2): 144-150.

Paul, Hermann. 1919/1954. Deutsche Grammatik. Halle: Niemeyer.

Penka, Doris, and Arnim von Stechow. 2001. Negative Indefinita unter Modalverben. In Modalität und Modalverben im Deutschen, eds. R. Müller, and M. Reis, 263-286. Hamburg: Buske. 
Pesetsky, David, and Esther Torrego. 2007. The syntax of valuation and the interpretability of features. In Phrasal and clausal architecture: Syntactic derivation and interpretation, eds. S. Karimi, V. Samiian, and W. K. Wilkins, 262-294. Amsterdam: Benjamins.

Poletto, Cecilia. 2008. On negation splitting and doubling. Handout. University of Venice.

Pollock, Jean-Yves. 1989. Verb movement, universal grammar, and the structure of IP. Linguistic Inquiry 20(3): 365-424.

Staudinger, Bernhard. 1997. Sätzchen: Small clauses im Deutschen. Tübingen: Niemeyer.

Tommaseo, Niccolò, and Bernardo Bellini. (1859-79) Dizionario della lingua italiana. Milano: Rizzoli. http://www.dizionario.org/.

Weiß, Helmut. 2002a. Three types of negation: A case study in Bavarian. In Syntactic microvariation, eds. S. Barbiers, L. Cornips, and S. van der Kleij, 305-332. Meertens Institute Electronic Publications in Linguistics.

Weiß, Helmut. 2002b. A quantifier approach to negation in natural languages. Or why negative concord is necessary. Nordic Journal of Linguistics 25: 125-153.

Westergaard, Marit. 2009. Microvariation as diachrony: A view from acquisition. Journal of Comparative Germanic Linguistics 12(1).

Zinsmeister, Heike. 2003. Negation in German. Doctoral dissertation, Universität Stuttgart. 